\title{
Islamic Political Parties in the Post-Truth Era
}

\author{
A. Bakir Ihsan \\ \{a.bakir.ihsan@uinjkt.ac.id\} \\ Universitas Islam Negeri Syarif Hidayatullah Jakarta, Indonesia
}

\begin{abstract}
Islamic political parties in Indonesia are faced with two dilemmas. Structural dilemmas and cultural dilemmas. Structurally, the principle of Islam is not compatible with the state ideology that places religion as a social value, not as a formal state reference. While culturally Islamic political parties do not show the uniqueness of their principles in aggregating and articulating people's aspirations. There is even a tendency to extend the role of Islamic political parties in an effort to gain support (electability) beyond the limits of its principles. These cultural and structural dilemmas are becoming increasingly crucial in the midst of the post-truth era. An era marked by the spread of lies that are reproduced massively so that they are transformed into truth. Islamic political parties with the dilemmas they face both culturally and structurally are not only unable to become a fortress that minimizes the spread of non-factual opinions, but also has the potential to become fertile ground for modification of lies wrapped in theology (politicization) of deviation-filled theology. This is in line with the development of religious identity politics which is part of power politics.
\end{abstract}

Keywords: Islamic principles, Islamic political parties, catch-all parties, post-truth, and democracy.

\section{Introduction}

Religion and democracy are two paradoxical systems. Religion bases itself on theological legitimacy, while democracy rests on sociological justification. Consequently, religion emphasizes the universalization of values that are top-down, while democracy refers to the actualization that is buttom-up. Social reality in the perspective of religion is placed as an object, while for democracy social reality as a subject. But in practice, these differences are subordinated in terms of interests incarnated in complex political practices. One of them is in the form of religious-based political parties [1].

Political parties as elements of democracy with all their "identities" actually don't have a direct relationship with religion, in fact they are in some respects contrary. But factually, there was an "affair" between the two, so that gave birth to ambiguity in the existence of political parties (democracy) itself. This is especially true in countries where people are very thick with religion, such as in Indonesia. Even according to Jonathan Fox's research most Western democracies do not separate religion from the democratic process [2].

All this happens because democracy offers a vast land of appreciation for a variety of understandings and beliefs. Even religions that are truly paradoxical with democracy use the opportunities offered by democracy for the "religious interests" themselves. An exclusive propaganda with universalistic values is played out in the public sphere which even, to a certain extent, threatens democracy itself. This can be seen from the phenomenon of rejection 
of a democratic system which is considered secular, even a system of kufr (contrary to Islam), and therefore it wants to be replaced by a religion-based system [3]. Ironically, the struggle to reject democracy is actually appreciated thanks to the freedom offered by democracy.

The consistency of democracy in providing space for freedom, actually gives opportunity to every understanding or ideology that develops in harmony with democracy itself. That is a conception of equality (equality) without discrimination between diverse groups of people both in terms of religion, culture, ethnicity, and others. This is where the problem arises because there is no conceptual alignment between democracy and religion in placing society.

This conceptual problem also served as the background for the long struggle between Islam and state politics at the beginning of the independence of the Republic of Indonesia. History in this Republic shows such a tug of war with religious interests in guarding the Republic's foundation. This is in line with the emergence of religious-based parties in the midst of a pluralistic society in terms of religion and belief. Moreover, the state does not base itself on certain religions or beliefs.

There are at least six indicators that the Indonesian state rejects the understanding of a religious state. First, the constitution recognizes and gives freedom for all its citizens to carry out their worship according to their religion and beliefs. Second, the state does not recognize an official religion as the state's seat. This is different from Malaysia which recognizes Islam as the official state religion. Third, the constitution does not determine the religion adopted by a head of state. Fourth, the state does not determine the religion recognized by the state. Fifth, since the abolition of the seven words that describe the principle of Godhead in the Jakarta Charter, Indonesia has become a secular state. Sixth, the rejection of the concept of an Islamic state in the session of the Constituent Assembly (1956-1959) and the rejection of the revival of the Jakarta Charter in the 2002 MPR Session [4].

Indonesia's decision to ordain itself as a country that houses a variety of religions, not certain religions, actually dilutes the interests of religious groups to reveal their interests in the domain of the state. Even indirectly this state system places religion as values, not institutions in the political process of the state. However, this does not appear to have been addressed unanimously. Proven in its journey, religion remains an obsessive reference for some groups through religious symbolization in carrying out their politics.

This was seen since the election was held in Indonesia. In the 1955 General Election the militants of Islamic-based parties emerged. The ideological attraction of Islam at that time was very strong because the basic existence of the state was still understood loosely. Even the political interests of Islam strongly colored the debate in the constituent assembly. The ties of Islamic political ideology at that time were very strong because basic state discourse and debate was still ongoing. This is not available at this time. The state constitution is based on the Pancasila ideology set out in the 1945 Constitution. This fact actually becomes the spirit and foundation of all political parties because in function it becomes an instrument of policy making for the plural public interest [5], but the fact is that the ideological political expression of Muslims is also not cracked. It was proven at the beginning of the New Order that political parties based on Islam continued to strengthen before finally being discussed by the government on the basis of political stability. Islamic-based parties are incorporated in the United Development Party. So that this party does not lead to the struggle for political Islam, the party chairperson's position must also be adjusted to the interests of the government. Especially since the establishment of the single principle of Pancasila which was operated by the New Order, all community forces, including political parties that historically have Islamic backgrounds, must unite in one principle, Pancasila. Actually, this single principle policy is both a translation and a consequence of the adoption of Pancasila as the state ideology. 
However, because the New Order used ideology as the medium of operation for its centralized and authoritarian power, the single principle of the Pancasila became lost in spirit as well as full of deviation.

That is why after the New Order, the ideology of Pancasila was the target of criticism which caused its existence to float. One side of the state needs an ideology, but the existing ideology is tainted by the distortion of power developed by the New Order government. Even Pancasila has become a virus that makes citizens allergic to remembering let alone make it a social reference, including political party references. This can be seen in the new principles of political parties that emerged at the beginning of the reform. The principle of Islam is one that sufficiently colors the founding of the party.

Political parties as the main media to gain power that oversees all social realities, requires the existence of equal treatment both conceptually and factually against plural reality. Therefore, the main problem that will occur when a religiously based political party (hereinafter referred to as a religious political party) wins the election and controls power in the life of the nation state is the fate of the religious principle. This problem does not occur in countries with religious ideology. But in a country like Indonesia that places religion only on social values, the religious principle of a party is a big question mark. Ambiguity occurs when parties based on religion move the state that is free from the religious system (ideology). On the other hand, if the religious party moves moderately, then it has denied the principle of its party as a religious party. The religious party failed to develop the mission and vision of its party as a religious party in the context of power.

Historically, this has happened in some secular democracies, such as in Belgium and Algeria. In both countries the religious party won the election. In Belgium at the end of the 19th century, the Catholic Party won elections held in 1884. The victory of the Catholic party turned out to succeed in continuing democracy in Belgium. The Catholic religion which forms the basis of the party has actually been successfully adapted to the interests of the state. While in Algeria, the Islamic Salvation Front (FIS) party won elections in 1992, but was later thwarted by the military [6].

The relationship between religion and democracy until now is still a tug of war between those who accept and those who refuse. Some observers consider that religion and democracy are two entities that must be separated. Democracy which is based on inclusive values will be threatened by the formalization and fragmented formalization of religion. Among the figures who have this point of view are [7][8][9]. According to Stepan, democracy is an institution that must be free from rules that actually curb or limit democracy, including religion:

Democratic institutions must be free, within the bounds of the constitution and human rights, to generate policies. Religious institutions should not have constitutionally privileged prerogatives that allow them to mandate public policy to democratically elected governments. At the same time, individuals and religious communities must have complete freedom to worship privately. In addition, as individuals and groups, they must be able to advance their values publicly in civil society and to sponsor organizations and movements in political society, as long as their actions do not impinge negatively on the liberties of other citizens or violate democracy and the law.

The tendency of religious infidelity in formal politics (read: political parties) is inseparable from the cultural reality of the community which from the beginning was very thick with religious values. This is different from political developments in the West which were born out of a process of secularization which places religion as a subordinate of political work. However, it cannot be denied that efforts to relate religion in practical politics still 
continue in even democratic Western countries. This shows that the problem of values and history is difficult to be separated from the social reality which is the basis for politics itself.

However, efforts to build a democratic system based on nationality and uphold plurality require ideological similarities across all pillars of democracy, especially political parties, with the state and democracy itself. More than that, true democracy is not wrapped with things that can lead to primordial exclusivity that can narrow the plurality space that is a concern for democracy.

\section{Structural and Cultur-Al Dilemmas}

The description above shows the dynamics of political and religious struggle under secular (non-religious) ideology. The existence of religious-based political parties has become its own agenda related to the implementation of political party agendas which are the elaboration of the principle it adheres to.

Indonesia, with its socio-cultural dynamics that are thick with religion, is difficult to let go of political problems with religion. That is the background of the emergence of Islamicbased political parties that are actually in contrast with the existence of Pancasila as a nonreligious ideology. Because it becomes an important question about the relationship of political parties as instruments of democracy with religion which is placed in the context of Indonesia as a civil religion, not the state religion.

Culturally, Indonesia cannot be separated from religion. Even the state requires its citizens to be religious. In other words, a citizen who does not embrace a religion recognized by the state does not have the right to become an Indonesian citizen. At this point the state indirectly tightens religious relations in state life. This is also the background for the emergence of a religious attitude in the political life that later incarnated in a religious-based political party.

An important question related to the existence of religious-based political parties in this non-religious country is what is the urgency of Islamic political parties for Indonesia which is in fact diverse in religion and culture. How far is the correlation between the Islamic principle of political parties with the activities and political agendas fought by these Islamic-based parties. This question is important because so far there has been no specific agenda championed by Islamic-based political parties for the formal interests of Muslims, except for the effort to re-enter the Jakarta Charter in the process of amending the 1945 Constitution in 2002. More than that, the political behavior exhibited by members of Islamic-based political parties is no different from other political parties that are based on Pancasila.

There are two interrelated factors that have led to the defense of religious links with political parties. First, culturally people still see religion as a consideration for choices in life, including choices in politics. It was proven in the 2004 election that Islamic-based political parties were still an option, even there was an upward trend. Second, politically, political parties make themselves available to uphold religious principles, sometimes even raising formal religious issues to attract the sympathy of Muslim voters.

Although from the beginning Indonesia ordained not as a religious state, but explicitly requires its citizens to be religious (god). Vice versa, although the state does not want to be called a secular state, but the implementation of democracy that is born free from religious factors requires the state to be neutral towards all religions and ward off the domination of certain religions in the public sphere. Even the true state gives a firm distance for the 
strengthening of religious-based political parties. This is the state's dilemma on the one hand, the political party's dilemma on the other.

For political parties based on Islam, they are faced with two interrelated dilemmas. First, structural dilemmas. The state ideology that places religion as a system of values and beliefs, closes the space of formalizing religion in the realm of the state. At this point, Islamic parties do not have the opportunity to contest in the realm of ideology because the state establishes a national ideology that is free from certain religious hegemony. National ideology becomes the foundation and reference of all existing systems in Indonesia and becomes an umbrella for all political forces under a unitary state.

Second, cultural dilemmas. Political parties have functions as agents of aggregation and articulation of people's aspirations. Therefore, in the context of Islamic political parties, the actual aggregation and articulation is focused on the issues that arise or problems that occur within Muslims. But in reality, among the many socio-religious problems of the Islamic community, not many were fought for or taken seriously by Islamic political parties. Khilafiyah cases that occur among various religious groups that often lead to violence cannot be addressed effectively by Islamic political parties. Whereas among the functions of political parties is conflict management [10].

These two dilemmas at the extreme point give the impression that the Islamic principle for political parties is no more a symbol of religious political (politicization) than a substantive agenda and function of the party. This was also strengthened by the political behavior of members of Islamic political parties whose capacity, capability and integrity were no better than those of political parties in general.

Observing the political behavior of Islamic parties reflected by their members does not fully show the correlation of Islamic principles. Their behavior is the same as the behavior of other politicians who are not based on Islam. In the case of corruption, for example, members of Islamic political parties are also part of it. Likewise with other deviant behavior. This is where the ambiguity between the principles of Islam with political behavior. This happens because the principle is no more than a mere identity, without actualized internalization in a person full of integrity and quality.

\section{Religion in the Post-Truth Era}

One of the main features of the post-truth era is the death of rationality and truth. An era that deifies emotions and beliefs about self-truth based on subjective data. The objectivity and truth of the institution as well as the facts that can be falsified as truth are collapsed by the engineering of opinion that is continuously infiltrated. Emotions are no longer grounded in right or wrong, but in truth beliefs built on engineering that are continually being preached so that they are convincing as truth. This is what colors Indonesian politics lately which is ironically partially clad in religious claims.

This reality becomes a challenge for Islam and democracy which at some point are ordained as interconnected realities in the context of Indonesianism. A fact that distinguishes Indonesia from other Muslim countries that are still wallowing in conflict and the threat of failure of democracy. Islamic political parties in Indonesia with the problems they contain are dealing with realities or eras that may be at certain points of interest intertwined because of incentives and pragmatic interests that are quite favorable. Political parties that are still institutionally fragile, are very likely to be part of the post-truth era. 
Politics in the post-truth era is driven more by actors who prioritize the attraction of emotions rather than ratios, putting forward the halal of all means, even lies, to achieve personal or group goals by ignoring collectivity based on truth and objectivity as multiple national entities. Knowledge and validity of the data are turned upside down by information that is continually exposed in the public sphere through a variety of social media which in turn turns the truth into mistakes and mistakes become truths. The powerlessness of religious politics (Islam) in dealing with hegemonic realities in the post-truth era is a signal of increasing ambiguity in religious and political relations in democracy.

The post-truth era actually becomes an opportunity that offers a strengthening space to place religion as a rational reinforcement of social integrity and cohesiveness [11]. Religious political parties that are culturally an expression of social-religious slices and structurally as an effective way in determining the direction of policy can place themselves more excessively in the middle of the post-truth era. All of this returns to the ability of religious political parties (Islam) to understand, process, and implement their steps and programs consistently with the tendency to strengthen post-truth culture that prioritizes the belief of non-truth emotionally.

\section{References}

[1] J. L. Esposito, Islam and Politics. New York: Syracuse University Press, 1992.

[2] J. Fox, "Do Democracies Have Separation of Religion and State," Can. J. Polit. Sci., 2007.

[3] S. A. Q. Zallum, Demokrasi Sistem Kufur: Haram Mengambilnya, Menerapkannya, dan Mempropagandakannya. Bogor: Pustaka Tharigul Izzah, 1994.

[4] F. Hassan and dkk, Restorasi Pancasila, Mendamaikan Politik Identitas dan Modernitas. Bogor: Brighten Press, 2006.

[5] M. Mas'oed and C. MacAndrews, Perbandingan Sistem Politik. Yogyakarta: Gajah Mada Unversity Press, 1990.

[6] S. N. Kalyvas, "Religion and Democratization," Belgium and Algeria, 1997.

[7] J. Rawls, Political Liberalism. New York: Columbia University Press, 1993.

[8] Demerath, Crossing the Gods: World Religions and Worldly Politics. New Jersey: Rutgers University Press, 2001.

[9] A. Stepan, "Religion, Democracy, and the 'Twin Toleration,"' J. Democr., vol. 11, no. 4, 2000.

[10] M. Budiardjo, Dasar-Dasar Ilmu Politik. Jakarta: Gramedia, 2008.

[11] D. Jacobsen and R. H. Jacobsen, "Faith and Learning in a Post-Truth World," J. Coll. Character, vol. 19, 2018. 